\title{
PRODUCTION OF THERMOSTABLE GLUCOAMYLASE BY NEWLY ISOLATED ASPERGILLUS FLAVUS A 1.1 AND THERMOMYCES LANUGINOSUS A 13.37
}

\author{
Eleni Gomes $^{1 *}$; Simone Regina de Souza ${ }^{1}$; Roseli Picolo Grandi² ${ }^{2}$ Roberto Da Silva ${ }^{1}$ \\ ${ }^{1}$ Laboratório de Bioquímica e Microbiologia Aplicada, IBILCE, Instituto de Biociências, Letras e Ciências Exatas, Universidade \\ Estadual Paulista, SP, Brasil; ²Seção de Micologia e Liquenologia, Instituto de Botânica, São Paulo, SP, Brasil
}

Submitted: October 21, 2004; Returned to authors for corrections: January 27, 2005; Approved: March 28, 2005

\begin{abstract}
Thirteen thermophilic fungal strains were isolated from agricultural soil, tubers and compost samples in tropical Brazil. Two strains were selected based on of their ability to produce considerable glucoamylase activity while growing in liquid medium at $45^{\circ} \mathrm{C}$ with starch as the only carbon source. They were identified as Aspergillus flavus A1.1 and Thermomyces lanuginosus A 13.37 Tsiklinsky. The experiment to evaluate the effect of carbon source, temperature and initial $\mathrm{pH}$ of the medium on enzyme production was developed in a full factorial design (2x2x3). Enzyme productivity was influenced by the type of starch used as carbon source. Cassava starch showed to be a better substrate than corn starch for glucoamylase production by A. flavus but for $T$. lanuginosus the difference was not significant. Enzyme activities were determined using as substrates $0.3 \%$ soluble starch, $0.3 \%$ maltose or $0.3 \%$ of starch plus $0.1 \%$ maltose. The enzymes from A. flavus A1.1 hydrolyzed soluble starch preferentially but also exhibited a significant maltase activity. Moreover higher quantities of glucose were released when the substrate used was a mixture of starch and maltose, suggesting that this fungus produced two types of enzyme. In the case T. lanuginosus A 13.37, the substrate specificity test indicated that the enzyme released also hydrolyzed starch more efficiently than maltose, but there was no increase in the liberation of glucose when a mixture of starch and maltose was used as substrate, suggesting that only one type of enzyme was secreted. Glucoamylases produced from A. flavus A1.1 and T. lanuginous A.13-37 have high optimum temperature $\left(65^{\circ} \mathrm{C}\right.$ and $\left.70^{\circ} \mathrm{C}\right)$ and good thermostability in the absence of substrate (maintaining $50 \%$ of activity for 5 and 8 hours, respectively, at $60^{\circ} \mathrm{C}$ ) and are stable over in a wide $\mathrm{pH}$ range. These new strains offer an attractive alternative source of enzymes for industrial starch processing.
\end{abstract}

Key words: Glucoamylase, $\alpha$-glucosidase, Aspergillus, Thermomyces

\section{INTRODUCTION}

The enzymes that hydrolyze starch can be divided into endoamylases, exoamylases and debranching amylases.

The endoamylases (EC 3.2.1.1) cleave $\alpha-1,4$ glycosidic bonds in amylose, amylopectin and related polysaccharides but not $\alpha-1,6$ linkages. The products of hydrolysis are oligosaccharides of varied chain lengths and have a $\alpha$-configuration on the $\mathrm{C}_{1}$ of the reducing glucose unit produced (8).

The exoamylases act preferentially on $\alpha-1,4$ linkages from the nonreducing end, successively, resulting in low molecular weight products. Currently two types of exoamylases are important for starch hydrolysis. Glucoamylase (EC 3.2.1.3) of fungal origin attacks $\alpha-1,4$ bonds, releasing D-glucose molecules in the $\beta$ configuration; this enzyme also attacks $\alpha-1,6$ bonds at branching points in the amylopectin molecule, but much more slowly than $\alpha-1,4$ linkages. $\alpha$-Glucosidase (EC 3.2.1.20) catalyzes the splitting of $\alpha$-D-glucosyl residues from the nonreducing end of substrates to release $\alpha$-glucose (9); $\beta$-amylase (EC 3.2.1.2) of plant or bacterial origin acts in an exo-fashion proceeding, from the nonreducing ends of the outer starch chains or related polysaccharides, gradual removal the romoving maltose units in the $\beta$-anomeric form (6).

*Corresponding Author. Mailing address: Departamento de Biologia, IBILCE, UNESP. R. Cristóvão Colombo, 2265, Jardim Nazareth. 15054-000, São José do Rio Preto, SP, Brasil. E-mail: eleni@bio.ibilce.unesp.br 
Debranching enzymes include pullulanase (EC 3.2.1.41) which acts specifically on $\alpha-1,6$ linkages in pullulan, starch, amylopectin and related oligosaccharides and isoamylase (EC 3.2.1.68), that hydrolyzes $\alpha-1,6$ linkages in amylopectin, but has a very low activity or no activity toward pullulan (8).

In industrial starch syrup production, the starch is liquefied in a first stage at $105-107^{\circ} \mathrm{C}$ for $5-15 \mathrm{~min}$, followed by a second stage for $60-180 \mathrm{~min}$ at $95-98^{\circ} \mathrm{C}$. Thermostable $\alpha$-amylases are used for starch hydrolysis in this liquefaction step. Upon completion of liquefaction, the slurry has to be cooled at 55$60^{\circ} \mathrm{C}$ before the saccharification step, since the glucoamylase from Aspergillus niger used in this stage is unstable at temperatures above $60^{\circ} \mathrm{C}(2 ; 17)$.

High value is placed on the extreme thermostability and thermoactivity of amylases used in the starch bioprocessing. Thus, for industrial purposes, new highly thermostable and environmentally compatible glucoamylases may make an important contribution to the starch processing industry.

On the other hand, the discovery, isolation, and application of different amylolytic enzymes have resulted in the development of new hydrolyzed starch products and in a wide variety of different syrup properties, which can be exploited in many applications.

The objectives of this study were to evaluate glucoamylase production in various culture conditions from newly-isolated thermophilic fungi and the physico-chemical characterization of these enzymes.

\section{MATERIALS AND METHODS}

\section{Isolation and identification of microorganisms}

Two g samples of agricultural soil, potato tubers, compost and animal manure were homogenized in sterile medium of $\mathrm{pH}$ 5.0 containing $1.0 \%$ soluble starch; $0.14 \%\left(\mathrm{NH}_{4}\right)_{2} \mathrm{SO}_{4} ; 0.20 \%$ $\mathrm{K}_{2} \mathrm{HPO}_{4} ; 0.02 \% \mathrm{MgSO}_{4} .7 \mathrm{H}_{2} \mathrm{O} ; 1.60 \mathrm{mg} / \mathrm{L} \mathrm{MnSO}{ }_{4} \cdot \mathrm{H}_{2} \mathrm{O} ; 1.40 \mathrm{mg} /$ $\mathrm{LZnSO}_{4} .7 \mathrm{H}_{2} \mathrm{O} ; 2.0 \mathrm{mg} / \mathrm{L} \mathrm{CoCl}_{2}$. After incubation at $45^{\circ} \mathrm{C}$ for $24 \mathrm{~h}$, a loop of the homogenized culture was streaked on the surface of the same medium containing 3.0\% agar and incubated at $45^{\circ} \mathrm{C}$ for 24 to $72 \mathrm{~h}$. All morphologically contrasting colonies were purified by repeated streaking. Pure cultures were subcultured on slants of the same medium for identification and enzyme studies. The identification of the fungi was based on morphological and biochemical characteristics (12). The stock cultures were maintained at $7^{\circ} \mathrm{C}$ on Potato Dextrose Agar medium (PDA).

\section{Production of amylases in submerged fermentation (SmF)}

Erlenmeyer flasks with $25 \mathrm{~mL}$ of medium containing $1.0 \%$ carbon source, $0.14 \%\left(\mathrm{NH}_{4}\right)_{2} \mathrm{SO}_{4}, 0.60 \% \mathrm{~K}_{2} \mathrm{HPO}_{4}, 0.20 \%$ $\mathrm{KH}_{2} \mathrm{PO}_{4}, 0.01 \% \mathrm{MgSO}_{4} 7 \mathrm{H}_{2} \mathrm{O}, 0.50 \%$ yeast extract, $0.20 \%$ peptone, $0.20 \%$ beef extract ( $\mathrm{pH} 5.0$ ) were inoculated with aliquots of mycelial suspensions (approx. $5.0 \mathrm{mg} / \mathrm{mL}$ ) of Thermomyces or spore suspensions $\left(10^{6} \mathrm{spores} / \mathrm{mL}\right)$ of Aspergillus, obtained from 7-day agar slant cultures suspended in sterile $0.01 \%$ Tween 80 solution. The fermentation was carried out in a rotary shaker at $100 \mathrm{rpm}$ for $96 \mathrm{~h}$ at the temperatures described below. The biomass was separated by centrifugation at $10000 \mathrm{~g}$ for $20 \mathrm{~min}$ and the supernatant was used to evaluate amylase activities.

\section{Effect of carbon source, initial pH of the media and temperature of incubation on enzyme production}

Corn or cassava starches $(1.0 \%)$ were used as carbon sources. The media $\mathrm{pH}$ was adjusted to $4.0,5.0$ or 6.0 and incubation temperatures were 40 or $45^{\circ} \mathrm{C}$. The experiment was developed in a full factorial design $(2 \times 3 \times 2)$ with three repetitions. For statistical analysis (ANOVA and Tukey test) the face software Estat was used.

\section{Enzyme activity measurement}

Enzyme activity was assayed at $60^{\circ} \mathrm{C}$ in a reaction mixture containing $0.5 \mathrm{~mL}$ of diluted crude enzyme solution and $0.5 \mathrm{~mL}$ of substrate solution in $0.25 \mathrm{M}$ sodium acetate buffer $\mathrm{pH}$ 5.0. The substrates used were $0.3 \%$ soluble starch, $0.3 \%$ maltose or a mixture of $0.3 \%$ soluble starch plus $0.1 \%$ maltose (16). The amount of glucose released was estimated by the peroxidase/ glucose oxidase assay (4). One unit of enzymatic activity (U) was defined as the amount of enzyme that releases one $\mu \mathrm{mol}$ of glucose per minute per $\mathrm{mL}$ of reaction.

\section{Enzyme characterization}

Optimum $\mathrm{pH}$ and temperature for enzyme activity: The optimum $\mathrm{pH}$ was determined by measuring activity at $60^{\circ} \mathrm{C}$ using various buffers: sodium acetate $(\mathrm{pH} 3.0-5.0)$, citrate-phosphate (pH 5.0-7.0), tris- $\mathrm{HCl}(\mathrm{pH} 7.0-8.5)$ and glycine- $\mathrm{NaOH}(\mathrm{pH} 8.5-$ 11.0). The optimum temperature was assayed by incubating each reaction mixture at $40^{\circ} \mathrm{C}$ up to $90^{\circ} \mathrm{C}$.

Thermostability: a thin layer of mineral oil prevented evaporation of the crude enzyme solution which was incubated at various temperatures $\left(10-90^{\circ} \mathrm{C}\right)$ for $1 \mathrm{~h}$ at $\mathrm{pH}$ 5.0. Another experiment was carried out to assay the enzyme stability at $60^{\circ} \mathrm{C}$. The enzyme solution was maintained at this temperature for a period of $9 \mathrm{~h}$. A control to evaluate a possible maltose hydrolysis was carried out using water instead crude enzyme. In both assays an aliquot was withdrawn and placed on ice before assayed for residual enzyme activity at the optimum $\mathrm{pH}$ and temperature.

pH stability: Crude enzyme was dispersed (1:1) in $0.1 \mathrm{M}$ buffer solutions $\mathrm{pH}$ 3.0-5.0 (sodium acetate), $\mathrm{pH}$ 5.0-7.0 (citratephosphate), $\mathrm{pH}$ 7.0-8.5 (tris- $\mathrm{HCl}$ ) and $\mathrm{pH}$ 8.5-11.0 (glycine$\mathrm{NaOH}$ ) and maintained at $25^{\circ} \mathrm{C}$ for $24 \mathrm{~h}$. An aliquot was used to determine the remaining activity at the optimum $\mathrm{pH}$ and temperature. 


\section{RESULTS AND DISCUSSION}

\section{Selection of strains with amylolytic activity}

Among the 13 thermophilic fungi isolated from the tested materials, two strains were selected for their ability to grow at $45^{\circ} \mathrm{C}$ on a liquid medium containing starch as the only carbon source and to produce considerable glucoamylase activity under these conditions. These strains were identified as Aspergillus flavus A1.1 and Thermomyces lanuginosus A13.37.

Effect of carbon source, media initial $\mathrm{pH}$ and temperature of incubation on glucoamylase production in submerged fermentation

The statistical analysis indicated that variables carbon source, $\mathrm{pH}$ and temperature influenced significantly the enzyme production. The type of starch source used as carbon source influenced the glucoamylase production by A.flavus A1.1, which was higher (with statistical significance at $1 \%$ level) in media containing cassava starch than in those with corn starch (Fig. 1a-f). No statistical difference was observed in the amounts of enzyme synthesized by T. lanuginosus A13-37 on the two carbon sources, but it can be observed that enzyme activity was higher in the medium containing cassava starch (Fig 2a-f). Since there are differences in the amylose and amylopectin composition and lipid contents of these starches $(3,5)$ (corn starch has approximately $28 \%$ amylose, $72 \%$ amylopectin and $6.0 \%$ lipids while cassava starch has approximately $17 \%$ amylose, $83 \%$ amylopectin and $0.1 \%$ lipids), these results suggest that the composition and differences in the molecular structure of the starch could affect the enzyme induction. Cruz et al. (7) observed that the ability of Rhizopus sp to produce amylolytic enzymes that liberate reducing units was higher when the carbon source was amylose rather than to amylopectin, and that corn amylose was a better inducer of enzyme than its homologue from potatoes.

Analysis of Fig. 1 indicated that enzyme synthesis by $A$. flavus A1.1 grown on cassava starch was significantly higher when the initial $\mathrm{pH}$ of the culture medium was 6.0 (5\% level by Tukey test). However the enzyme activity was higher when the initial $\mathrm{pH}$ of the culture medium was 4.0 than when it was 5.0 (Fig. 1c to 1f), indicating that two forms of enzyme may have been produced. Enzyme synthesis by T. lanuginosus A.13.37 was higher at $\mathrm{pH} 5.0$ and 6.0 than at $\mathrm{pH} 4.0$ for both substrates.

Considering that the total growth of the microorganisms was significantly not affected by the $\mathrm{pH}$ of the media (data not shown), the effect of $\mathrm{pH}$ must be related to mechanisms regulating enzymatic synthesis and secretion. A similar effect of $\mathrm{pH}$ on production and secretion of glucoamylase (GA) by $A$. niger was described by Wallis et al. (22). They demonstrated that GA production was higher at $\mathrm{pH} 4.0$ than at $\mathrm{pH}$ 5.5. Since enzyme activity was not correlated with biomass production, the authors speculated that $\mathrm{pH}$ and the high level of produced gluconic acid controlled some aspects of enzyme production. Characterization of the $\mathrm{pH}$ signal transduction pathway in $A$. nidulans has been completed at the molecular genetics level, although the biochemical functions of the proteins involved still have yet to be elucidated (10).

Regarding the incubation temperature no statistically significant differences were detected in the enzyme synthesis when fermentation was carried out at 40 or $45^{\circ} \mathrm{C}$, although higher activities were observed in some assays at $40^{\circ} \mathrm{C}$ (Figs. 1 and 2).

To test the substrate-specificity, enzyme activities were determined with $0.3 \%$ soluble starch, $0.3 \%$ maltose or $0.3 \%$ starch plus $0.1 \%$ maltose as substrate. The results shown in Fig. 1 indicated that the enzymes produced by A. flavus A1.1 preferentially hydrolyzed starch (significantly $1 \%$ level) and exhibited a low maltase activity. On the other hand, crude enzyme released the highest quantities of glucose when the substrate used was a mixture of starch and maltose (Fig. 1e, 1f).

In the case of enzymes from T. lanuginosus A 13.37, the data of Fig. 2 indicate that the enzyme was able to hydrolyze starch more efficiently than maltose, but differently from A. flavus enzyme its activity on maltose was considerable. Moreover, there was no increase in the glucose liberated when a mixture of starch and maltose was used as substrate.

Although $\alpha$-glucosidase and glucoamylase are essentially differentiated by the produced anomer $(\alpha$-glucosidase produces $\alpha$-glucose and glucoamylase, $\beta$-glucose (6)), according to Saha and Zeikus (16) the $\alpha$-glucosidase activity can be determined in the presence of glucoamylase by comparing the results of incubating the enzyme with starch or with starch plus maltose. The higher yield of glucose from the second substrate gives evidence of the presence of $\alpha$-glucosidase. In this way, the results indicated that both glucoamylase and $\alpha$-glucosidase may be secreted into the cultivation medium by A. flavus. The presence of both enzymes has been reported in culture media of A. awamori, A. niger and A. oryzae $(18,19,20)$ and it was determined that the $\alpha$-glucosidase from these fungi hydrolyses not only maltose and malto-oligosaccharides, but also hydrolyses soluble starch very slowly, while glucoamylase is a starch-hydrolase capable of also degrading starch (6).

On the other hand, Tosi et al. (21) reported that a purified glucoamylase from $\mathrm{H}$. grisea showed considerable maltase activity, however the optima $\mathrm{pH}$, profiles response temperature and also the activation energies for hydrolysis of starch and maltose were different. Similar characteristics were described for glucoamylase from Scytalidium thermophilum (4). This pattern of activity in glucoamylase has been attributed to the existence of a common catalytic site for starch and maltose hydrolysis, but specialized subsites for each of these substrates. The presence of various subsites in the enzyme was also demonstrated for $\alpha$-glucosidase from Mucor javanicus and $A$. niger. $M$. javanicus $\alpha$-glucosidase has high activity on maltooligosaccharide and on soluble starch. This enzyme 

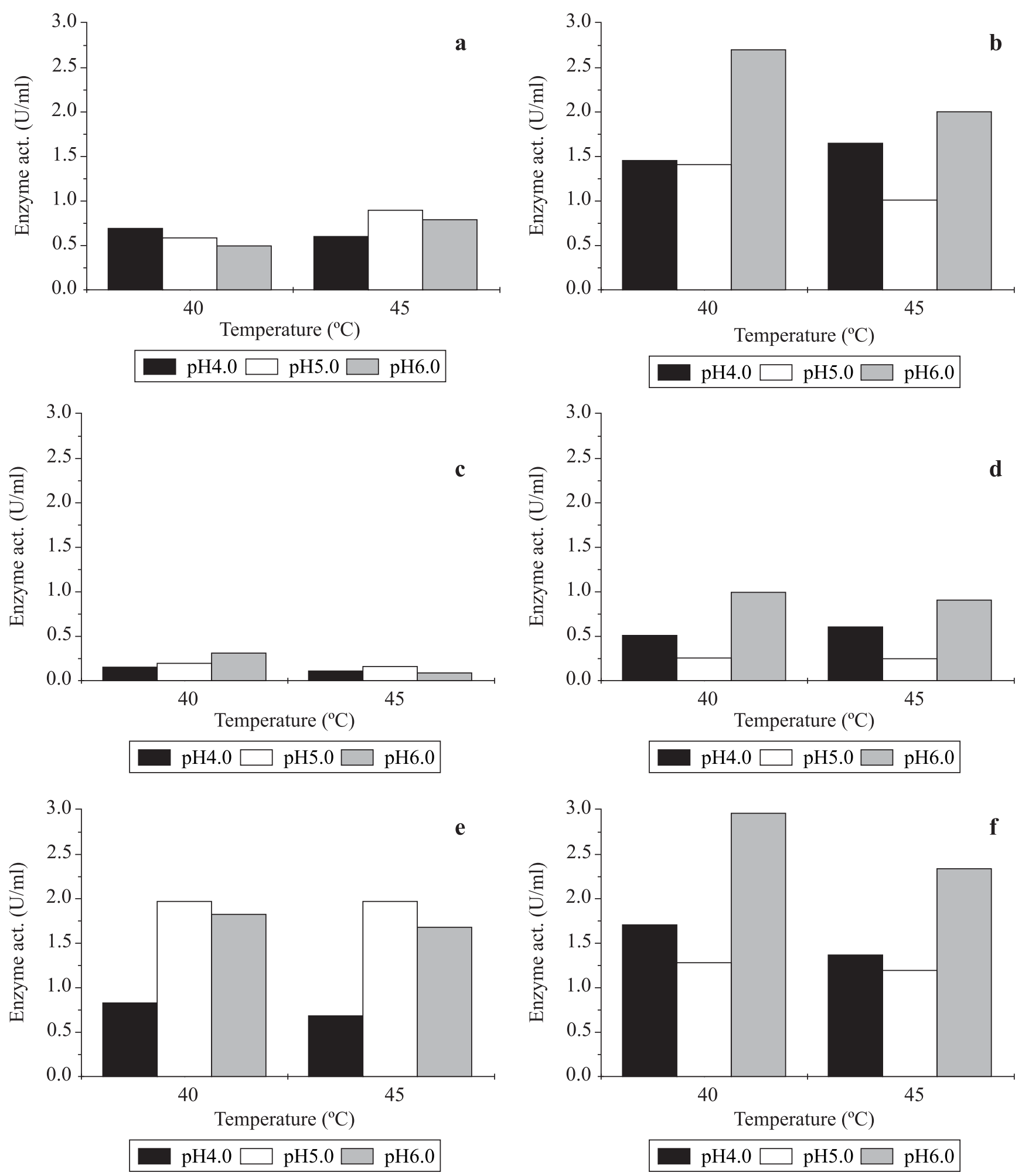

Figure 1. Effect of $\mathrm{pH}$, temperature and carbon source as a function of temperature on the glucoamylase production by Aspergillus flavus A1.1 determined with $0.3 \%$ starch $(\mathrm{a}, \mathrm{b}), 0.3 \%$ maltose $(\mathrm{c}, \mathrm{d})$ and $0.3 \%$ starch plus $0.1 \%$ maltose (e, f). Culture media were supplemented with $1 \%$ corn starch $(\mathrm{a}, \mathrm{c}, \mathrm{e})$ or $1 \%$ cassava starch $(\mathrm{b}, \mathrm{d}, \mathrm{f})$. 

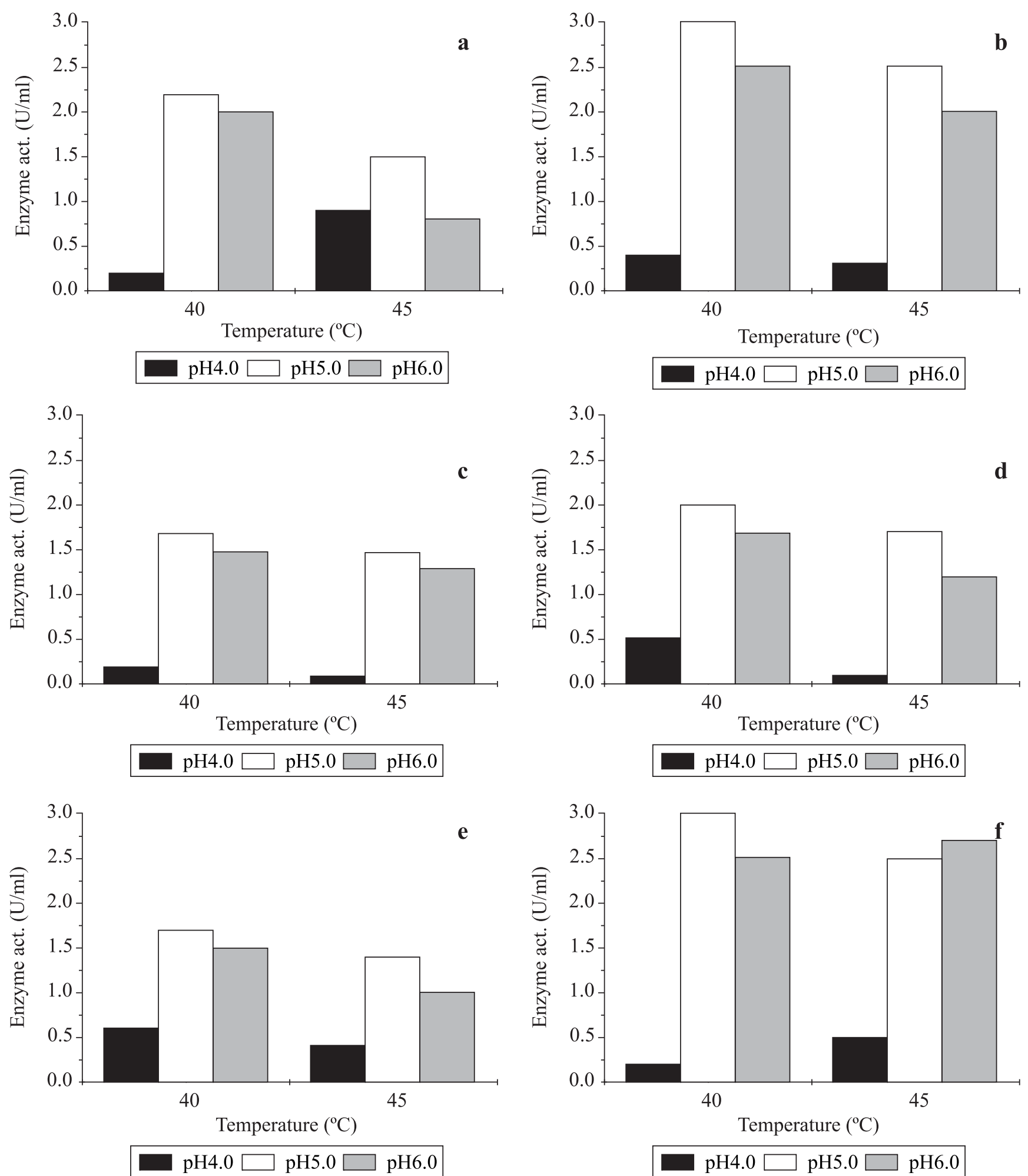

Figure 2. Effect of $\mathrm{pH}$, temperature and carbon source as a function of temperature on the glucoamylase production by Thermomyces lanuginosus 14.37 determined with $0.3 \%$ starch $(\mathrm{a}, \mathrm{b}), 0.3 \%$ maltose $(\mathrm{c}, \mathrm{d})$ and $0.3 \%$ starch plus $0.1 \%$ maltose (e, f). Culture media were supplemented with $1 \%$ corn starch $(a, c, e)$ or $1 \%$ cassava starch $(b, d, f)$. 
hydrolyses maltose and soluble starch at a single active site and has six subsites, which are more extended than other described subsites. This extended subsite structure binds the maltoligosaccharide firmly on the bond-cleavage site; however, the smallest substrate, maltose, would be bound in a nonproductive configuration and would be slowly hydrolyses when compared with larger maltooligosaccharides (18). In $\alpha$ glucosidase from A. niger, three subsites have been determined; this enzyme preferentially hydrolyses maltooligosaccharide and maltose and hydrolyses soluble starch slightly (10). This difference in substrate specificity is due to subsite structure (19).

Our results support that $A$. flavus produces two different enzymes while $T$. lanuginosus seems to produce one enzyme with a preference for soluble starch, but it is not possible to infer whether it is a glucoamylase or $\alpha$-glucosidase. Further investigations are required.

\section{Enzyme characterization}

The glucoamylase activities in the crude filtrates obtained from Aspergillus flavus and Thermomyces lanuginosus cultivation were characterized in terms of $\mathrm{pH}$ and temperature optima and stability. The enzyme from $A$. flavus exhibited maximum activity at $\mathrm{pH}$ 4.0. Approximately $86 \%$ of this activity was observed at $\mathrm{pH}$ 3.5 and $57 \%$ at $\mathrm{pH} 7.0$, indicating the enzyme showed activity over a wide $\mathrm{pH}$ range (Fig. 3a). The enzyme showed optimum activity at $65^{\circ} \mathrm{C}$ and $40 \%$ of this activity at $70^{\circ} \mathrm{C}$.

Enzyme from T. lanuginosu showed maximum activity at $\mathrm{pH}$ 4.5 and $67 \%$ of this activity at $\mathrm{pH} 4.0$ and at 5.5 (Fig. 3a). Optimum temperature for its activity was determined to be $70^{\circ} \mathrm{C}$ and the enzyme showed $67 \%$ of maximum activity at $75^{\circ} \mathrm{C}$ (Fig. $3 \mathrm{~b}$ ).

As illustrated in Fig. 3a, enzyme from A. flavus was stable over wide $\mathrm{pH}$ range, with $100 \%$ stability at values of 5.0-9.0 and $80 \%$ of this activity retained at $\mathrm{pH} 3.0$ and $90 \%$ at $\mathrm{pH} 10.0$. Glucoamylase from Thermomyces was more stable at $\mathrm{pH}$ 7.08.0 , retaining $55 \%$ of its activity at $\mathrm{pH} 3.0$ and $75 \%$ at $\mathrm{pH} 10.0$.

Enzyme produced by Aspergillus lost only $20 \%$ of the initial activity after $1 \mathrm{~h}$ at $60^{\circ} \mathrm{C}$ with total inactivation at $80^{\circ} \mathrm{C}$, while glucoamylase from Thermomyces showed an enhanced of $30 \%$ in relation to the original activity, after being maintained at $50^{\circ} \mathrm{C}$ for $1 \mathrm{~h}$. After $1 \mathrm{~h}$ at $60^{\circ} \mathrm{C}$, the activity of enzyme was $20 \%$ higher than the initial activity.

The thermostability of enzymes at $60^{\circ} \mathrm{C}$ was high. The enzyme from Aspergillus retained $85 \%$ of this activity after $1 \mathrm{~h}$ and $45 \%$ after $7 \mathrm{~h}$ at this temperature. The glucoamylase produced by Thermomyces increased its activity (20\%) when maintained for $1 \mathrm{~h}$ at $60^{\circ} \mathrm{C}$. After $8 \mathrm{~h}$ at $60^{\circ} \mathrm{C}, 55 \%$ of the initial activity was observed (Fig. 3c).

The optimum $\mathrm{pH}$ found for the Aspergillus glucoamylase is comparable to those from other Aspergillus species which have optimum activity in the $\mathrm{pH}$ range 4.0-5.5 such as the enzymes from A. terreus and A. tamari ( $\mathrm{pH} 4.0)$ and A. niger ( $\mathrm{pH}$ 5.0)
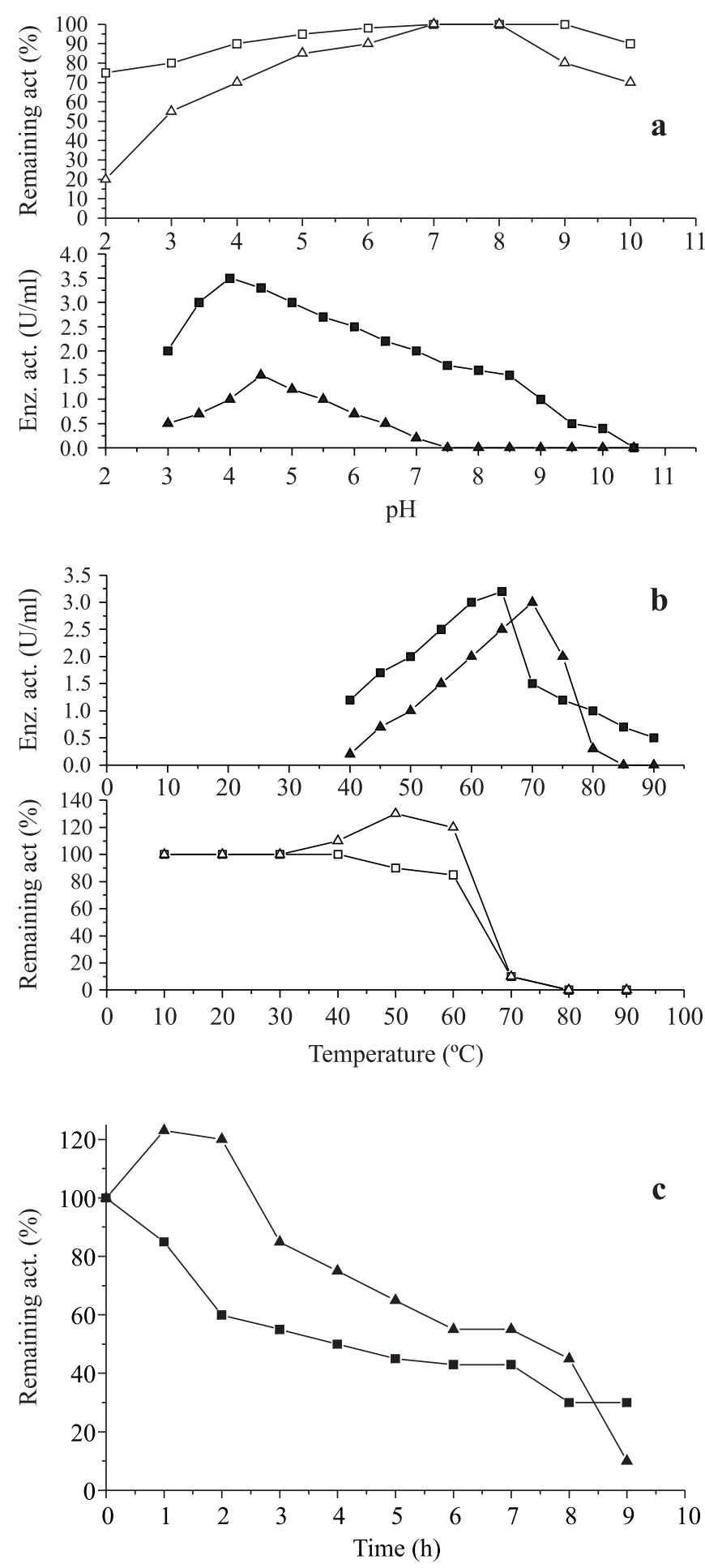

Figure 3. Physico-Chemical characterization of enzymes produced by A. flavus (square) and T. lanuginosus (up to triangle): Effect of $\mathrm{pH}$ (a) and temperature (b) on the enzymes stability in absence of substrate (open symbol) and activity in presence of substrate (full symbol); stability of enzyme at $60^{\circ} \mathrm{C}$ (c). 
$(1 ; 13)$. However, for Thermomyces species, glucoamylases have been described with which neutral $\mathrm{pH}$ optimum, such as those from H. grisea ( $\mathrm{pH} \mathrm{6.0)} \mathrm{and} \mathrm{H.} \mathrm{lanuginosus} \mathrm{(pH} \mathrm{6.6)} \mathrm{(4).}$

In comparison with the thermal characteristics of known glucoamylases, the enzymes differed in terms of their thermal stabilities and optimum temperatures $\left(65\right.$ and $\left.70^{\circ} \mathrm{C}\right)$ from those of several mesophilic fungal species whose optimum temperatures are between 40 and $50^{\circ} \mathrm{C}$, e.g. glucoamylases from Aspergillus and Rhizopus strains which are described as susceptible to denaturation at temperatures above $60^{\circ} \mathrm{C}(9,20)$. The enzymes were similar to glucoamylases from thermophilic fungi such as Talaromyces duponte, Thermomyces lanuginosus and $\mathrm{H}$. grisea that have optima at 75,70 and $60^{\circ} \mathrm{C}$, respectively (15).

Since any industrial process is based on the use of crude or partially purified enzymes, it is important to determine the optimum temperature for activity and thermostability under these conditions. Although $\alpha$-amylases used in the commercial production of sugar syrups from starch are sufficiently stable at the high operating temperatures, the enzymes employed for saccharification and for debranching of amylopectin are more thermolabile. Thus, glucoamylases with greater thermostability and active at higher temperatures are required.

Besides thermostability, the stability and activity over a wide $\mathrm{pH}$ range are important properties of the enzymes produced by the strains studied in this work. During saccharification, the $\mathrm{pH}$ of the liquefied slurry is adjusted down to 4.2-4.5, to move it closer to $\mathrm{pH}$ optimum for Aspergillus niger GA. Using enzymes that function over a wide $\mathrm{pH}$ range would eliminate this adjustment step.

In conclusion, glucoamylases produced from A. flavus A1.1 and T. lanuginosus A.13-37 have high optimal temperatures $\left(65^{\circ} \mathrm{C}\right.$ and $\left.70^{\circ} \mathrm{C}\right)$ with good thermostability in the absence of substrate (they maintained 50\% of activity for 5 and $8 \mathrm{~h}$ respectively at $60^{\circ} \mathrm{C}$ ) and stable activity over a wide $\mathrm{pH}$ range. With these characteristics they offer an attractive alternative source of enzymes for industrial starch processing.

\section{ACKNOWLEDGEMENTS}

The authors wish to thank the Fundação de Amparo à Pesquisa do Estado de São Paulo (FAPESP) for financial support.

\section{RESUMO}

\section{Produção e glucoamilase por Aspergillus flavus A1.1 e Thermomyces lanuginosus A13.37}

Entre 13 linhagens de fungos filamentosos isolados a partir de amostras de solo agrícola, tubérculos e de material em compostagem, duas foram selecionadas em função da capacidade de crescer em meio líquido contendo amido como única fonte de carbono, a $45^{\circ} \mathrm{C}$, e produzir consideráveis quantidades de glucoamilase. Essas linhagens, identificadas como Aspergillus flavus A1.1 e Thermomyces lanuginosus A13.37, foram utilizadas para desenvolvimento de experimentos para avaliar os efeitos do tipo de amido (milho e mandioca), do pH inicial do meio de cultura $(4,0 ; 5,0$ e 6,0$)$ e da temperatura de incubação $\left(40\right.$ e $\left.45^{\circ} \mathrm{C}\right)$, em um modelo fatorial $(2 \times 3 \times 2)$, sobre a produção da glucoamilase. O tipo de amido usado como fonte de carbono para o cultivo dos fungos influenciou significativamente a produção de glucoamilase por A. flavus, sendo obtida uma maior quantidade da enzima em meio contendo amido de mandioca do que em meio com amido de milho. A produção da enzima por $T$. lanuginosus também foi maior em meio contendo amido de mandioca, porém, a diferença não foi estatisticamente significativa. As atividades enzimáticas sobre amido $(0,3 \%)$, maltose $(0,3 \%)$ ou sobre mistura de $0,3 \%$ de amido com $0,1 \%$ de maltose, indicaram que as enzimas de Aspergillus hidrolisaram, preferencialmente, o amido, embora tenham mostrado atividade considerável sobre a maltose. A maior liberação de glicose a partir da mistura de substratos sugeriu que o fungo em questão possa secretar dois tipos diferentes de enzimas. Enzimas produzidas por T. lanuginosus hidrolisaram o amido e a maltose e não liberaram maiores teores de glicose quando o substrato constou de mistura de amido e maltose. As enzimas de Aspergillus e Thermomyces apresentaram elevada temperatura ótima de atividade $\left(65 \mathrm{e} 70^{\circ} \mathrm{C}\right.$, respectivamente $)$ com boa termoestabilidade na ausência de substrato (manutenção de $50 \%$ da atividade por 5 e $8 \mathrm{~h}$ respectivamente), além de estabilidade em ampla faixa de $\mathrm{pH}$. Os resultados apresentados indicam uma importante fonte alternativa de glucoamilase para uso no processamento industrial de amido.

Palavras-chave: Glicoamilase, $\alpha$-glicosidase, Aspergillus, Thermomyces

\section{REFERENCES}

1. Ali, S.; Hossain, Z. Characteristics of glucoamylase from Aspergillus terreus. J. Appl. Bacteriol., 71: 144-146, 1991.

2. Brumm, P.J. Enzymatic production of dextrose. Cereal Food World, 40: 804-804-807, 1998.

3. Cereda, M.P. Propriedades gerais do amido, Fundação Cargill, Campinas, 2001, v.1, 224 p.

4. Cereia, M.; Terenzi, H.F.; Jorge, J.A.; Greene, L.J.; Rosa, J.C.; Polizeli, M.L.T.M. Glucoamylase activity from the thermophilic fungus Scytalidium thermophilum. Biochemical and regulatory properties. J. B. Microbiol., 40: 83-92, 2000.

5. Chavez, R.A.P.; Carvalho, J.C.M.; Perego, P.; Tavares, L.C. Production of alpha-amylase and glucoamylase from different starches by a new Trichoderma sp isolate. Ann. Microbiol., 54: 169$180,2004$.

6. Chiba, S. Molecular mechanism in $\alpha$-glucosidase and glucoamylase Biosci. Biotech. Biochem., 61: 1233-1239, 1997.

7. Cruz, R.; Souza, E.L.; Hoffmann, E.H.E.; Bellini, M.Z.; Cruz, V.A.; Vieira, C.R. Relationship between carbon source, production and pattern action of $\alpha$-amylase from Rhizopus sp. Rev. Microbiol., 28 101-105, 1997. 


\section{E. Gomes et al.}

8. Guzman-Maldonato, H.; Paredes-Lópes O. Amylolytic enzymes and products derived from starch: a review. Crit Rev. Food Sc. Nut., 35: 373-403, 1995.

9. James, J.A.; Lee, B.H. Glucoamylases: Microbial sources, industrial application and molecular biology-A review. J. Food Biochem., 21: $1-52,1997$.

10. Kaia, A.; Matsui, H.; Somoto, A.; Kimura, A.; Takata, M.; Chiba, S Substrate specificity and subsite afinities of cristaline $\alpha$-glucosidase from Aspergillus niger. Agric. Biol. Chem., 55: 3237-2335, 1991.

11. Kaur, P.; Satyanarayana, T. Production and starch saccharification by a thermostable and neutral glucoamylase of a thermophilic mould Thermomucor indicae-seudaticae. World J. Microbiol. Biotecnol., 20: 419-425, 2004.

12. Kirk, P.M.; Cannon, P.F.; Daird, J.C.; Stalpers, J.A. Ainsworth Bisby's Dictionary of the Fungi. CAB International, Wallingford. $9^{\mathrm{a}}$ ed. 2001. 655 p.

13. Moreira, F.G.; Lima, F.A.; Pedrinho, S.R.F.; Lenatorviez, V.; Souza, C.G.M.; Peralta, R.M. Production of amylases by Aspergillus tamari. Rev. Microbiol., 30: 157-162, 1999.

14. Negret Urtasun, S.; Reiter, W.; Diez, E.; Denison, S.H.; Tilbur, J.; Espeso, E.A.; Penalva, M.A.; Arst, H.N. Ambient pH signal transduction in Aspergillus: completion of gene characterization. Mol. Microbial., 33: 994-1003, 1999.

15. Nguyen, Q.; Rezessy-Szabó, J.M.; Claeyssens, M.; Stals, I.; Hoschke, Á. Purification and characterization of amylolytic enzymes from thermophilic fungus Thermomyces lanuginosus strain ATCC 34626. Enz. Microbial Technol., 31: 345-352, 2002.

16. Saha, B.C.; Zeikus, J.G. Microbial glucoamylases: biochemical and biotechnological features. Starch/Stärk, 41: 57-64, 1989.

17. Satyarayana, T.; Noorwez, S.M.; Kumar, S.; Rao, J.L.M.; Ezhilvannan, M.; Kaur, P. Development of an ideal starch saccharification process using amylolytic enzymes from thermophiles. Biochem. Soc. Trans., 32: 276-278, 2004.

18. Sugimoto, M.; Ohta, T.; Kawai, F. Change in maltose and soluble activities of chimeric $\alpha$-glucosidase of Mucor javanicus and Aspergillus oryzae. Biochem. Bioph. Acta, 1645: 1-5, 2003.

19. Sugimoto, M.; Suzuki, Y. Hydrolytic action on the mixture of maltose and soluble starch by $\alpha$-glucosidase from Mucor javanicus IFO 4570. Biosci. Biotech. Bichem., 58: 1535-1536, 1994.

20. Swift, R.H.; Wiebe M.G.; Robson G.D.; Trinci A.P.J. Recombinant glucoamylase production by Aspergillus niger $\mathrm{B} 1$ in chemostat and pH auxostat cultures. Fungal Gen. Biol., 25: 100-109, 1998.

21. Tosi, L.R.O.; Terenzi, H.F.; Jorge, J.A. Purification and characterization of an extracellular glucoamylase from the thermophilic fungus Thermomyces grisea var. termoidea. Can. J. Microbiol., 39: 846-852, 1993.

22. Wallis, G.L.F.; Swift, R.J.; Atterbury, R.; Trappe, S.; Rinas, U.; Hemming, F.W.; Wieb, M.G.; Trinci, A.P.J.; Peberdy, J.F. The effect of pH on glucoamylase production, glicosylation and chemostat evolution of Aspergillus niger. Bioch. Bioph. Acta, 32: -112-122, 2001. 